\title{
Board of Directors and Financial Reporting Quality in Vietnam Listed Companies
}

\author{
Nguyen Thi Thanh Phuong ${ }^{1} \&$ Dang Ngoc Hung ${ }^{2}$ \\ ${ }^{1}$ Thuongmai University, Vietnam \\ ${ }^{2}$ Hanoi University of Industry, Vietnam \\ Correspondence: Dang Ngoc Hung, Hanoi University of Industry, Vietnam.
}

Received: February 10, 2020

Accepted: March 18, 2020

Online Published: July 7, 2020

doi:10.5430/ijfr.v11n4p296

URL: https://doi.org/10.5430/ijfr.v11n4p296

\begin{abstract}
This article studies the impact of the Board of Directors (BOD) on financial reporting quality (FRQ) in Vietnam listed companies. The research uses FEM, REM and GLS regression models, data collected at energy enterprises listed on the stock market in Vietnam from 2010 - 2018, with 2162 observations. The research results have found that the BOD size, BOD independence, BOD chairperson cum CEO has a positive impact on FRQ while BOD meeting frequency has a negative impact on FRQ. In addition, the audit quality, the ratio of liabilities has a positive impact on FRQ while company size has a negative impact on FRQ. Further, the percentage of female BOD members does not have an impact on FRQ. Empirical research results serve as a useful basis for enterprises to improve FRQ by considering of factors of the board of director in a more effective manner.
\end{abstract}

Keywords: board of directors, financial reporting quality, earning managenent, Vietnam

\section{Introduction}

Financial statements are one of the information channels that listed companies are required to provide on the stock market. FRQ is the determinant for an efficient financial market. In the stock market, listed companies are the information providers, investors are the main object to receive and use such information in their decision-making process. Nevertheless, how information is presented and made available to meet user needs still leaves a big gap between expectations and reality. FRQ relies on the quality of the listed companies' creation, presentation and disclosure process, which is under the impact of many internal and external factors.

The concept and measurement of FRQ in nowadays world are viewed by researchers from many different angles. Most studies have measured FRQ indirectly through such behaviors as Earning Management, Financial Restatement, Financial Statement Fraud (Schipper \& Vincent, 2003), (Cohen, Krishnamoorthy, \& Wright, 2004). However, FRQ here takes into consideration mainly from the perspective of financial information. Financial reporting information today is not restricted to information in financial statements in the traditional sense, but also is understood in a broader concept. In addition to financial information aiming to be useful for the decision-making process of financial information users. Especially for those outside enterprises (most of them are investors analyzers), financial reporting information must also provide non-financial information such as reports and analysis by managers, auditors' statements and other reports (Van Beest, Braam, \& Boelens, 2009).

Financial statements provide useful information about financial positions, operating results, cash flows and other additional information, enable information users to make economic decisions (Epstein \& Jermakowicz, 2008), (Mackenzie et al., 2012). The useful level of financial information depends largely on the quality of profit information (Ball \& Shivakumar, 2005). Profit information and its components play an increasingly important role for stakeholders to measure the business performance and predict future cash flows (P. M. Dechow, Kothari, \& Watts, 1998).

Presently, studies of BOD and FRQ have been conducted by researchers around the world such as Marrakchi Chtourou, Bedard, \& Courteau, 2001; Klein, 2002; Xie, Davidson, \& DaDalt, 2003, etc. It is noticeable that the authors' findings are heterogeneous when considering the impact of BOD characteristics on FRQ. For example, the characteristics of BOD independent members in the study by Xie et al., 2003; Ebrahim, 2007; Shehu Usman Hassan \& Ahmed, 2012 increase FRQ, meanwhile these do not affect FRQ in the studies by Murhadi, 2011; Gulzar, 2011; Soliman \& Ragab, 2014; Chaharsoughi \& Rahman, 2013; Chalaki, Didar, \& Riahinezhad, 2012. Or the factor of BOD 
size is directly related to FRQ such as Al-Othman \& Al-Zoubi, 2019, whereas in the study by Hashim \& Devi, 2008, BOD size has a negative impact on FRQ, and in the study by Chaharsoughi \& Rahman, 2013, BOD size does not have an impact on FRQ.

So, with heterogeneous findings, in Vietnam, a growing economy, what is the impact of BOD on FRQ? An adequate and comprehensive study of BOD characteristics influencing FRQ in Vietnam will be of great significance.

\section{Theoretical Framework}

\subsection{Agency Theory}

Agency theory (Jensen \& Meckling, 1976), also known as authorization theory, focuses on the relationship between the owner (authorizer) and the proxy (representative). The issue of representation inevitably gives rise to conflict between the authorizer and the representative, between shareholders and creditors. To resolve these contradictions, managers will impact on the accounting data, on the arising economic operations to ensure the harmonization of the parties' interests. Specifically, the agency theory is applied to explain the concurrent holding of CEO position of BOD chairperson, BOD size, BOD independence through the ratio of non-executive BOD members, number of BOD meetings, type of audit company, impacting on FRQ. (Watson, Shrives, \& Marston, 2002), according to the agency theory, the main purpose of financial reporting is to monitor the performance of managers, while managers use the announcement to convince shareholders that they act in the best way. Audit plays a role in overseeing for shareholders, as it can detect material errors in the company's financial statements, thereby minimizing conflicts between managers and owners.

\subsection{Stakeholder Theory}

Stakeholder theory is a point of view on management strategy and ethics, firstly introduced by Freeman, 1984. The central idea of this theory is that the success of an organization relies on the relationship between the manager and stakeholders such as investors, creditors, workers, customers, suppliers, state and others entities involved in achieving the corporate goals. There have been quite a few studies applying the stakeholder theory to justify the study findings. The stakeholder theory supports any company whose BOD is large-sized and varied and will be suitable and very convenient for linking the components. In addition to using the agency theory, the stakeholder theory is also combined to explain the BOD factors that impact on FRQ.

\subsection{Signalling Theory}

Signalling theory was introduced by Spence, 1973 . When studying the labour market, he observed that hiring workers is an uncertain decision as they do not know how the true competence of workers is. Ross, 1977 argued that the inherent contradictions between shareholders and managers cause managers to focus on providing central signals to meet the basic information needs of users. In the financial market, the primary relationship between shareholders and managers is exhibited through return on investment; the investor makes economic decisions based on profitability indicators. From this theoretical background, studies expand into the financial market and find that highly profitable companies will use explanatory notes to provide signals to improve their competitiveness. Managers can choose the best time to disclose good information or hide or delay the provision of adverse information to the outside or even perform tricks to change such adverse information.

\subsection{Resource Dependency Theory}

Pfeffer \& Salancik (1978) introduced the resource dependency theory, i.e. a theoretical foundation for the BOD resource role of enterprises. They think that operations of organizations will be interdependent and that resources will contribute to strengthening the company's organizational and operational functions. It is necessary for the BOD to administer the interdependence between organizations and ensure the resources and information they need. Hillman \& Dalziel, 2003 assumed that an ideal BOD should consist of many individuals with external links such as business experts, support professionals and communities that affect access to resources necessary for the company. Theorists of resource dependency ague that a varied and BOD with representatives of external independent members can improve corporate activities, particularly when there is a major change in the operating environment (Nicholson \& Kiel, 2007; Hillman \& Dalziel, 2003). Enterprises with larger or more varied BODs will be more advantageous to enjoy and maintain such important resources as human capital, social capital and legal knowledge (Xie et al., 2003; Peasnell, Pope, \& Young, 2005).

\section{Litterature Review}

Dechow \& Schrand (2010) studied FRQ measurement, factors influencing and results of FRQ including 6 groups of factors: (1) company characteristics including business performance, indebtedness status, growth, investment and size 
of the company, (2) practice including accounting methods, other methods based on principles and on regulations and practice of financial statements, (3) corporate governance and internal audit including the BOD, capital ownership percentage, employment policies, internal control mechanism, etc. (4) Audit includes business risks, type of audit company, auditor independence, etc. (5) capital market dynamics including dynamics upon the company's capital increase, profit targets achieved, and (6) other external factors such as capital market requirements, political process, tax-related provisions... and each study often focuses on one of groups of factors above. Qinghua, Pingxin, \& Junming, 2007 studied the relationship between audit committee, BOD characteristics and FRQ, empirical research on the Chinese stock market, these authors measured FRQ of the listed companies through earnings management (EM) by the modified Jones model. Factor influencing FRQ are divided (by Qinghua et al., 2007) into 3 groups: Firstly, components to the BOD are characterized by including (1) the percentage of independent directors in the BOD, (2) concurrent holding the positions of CEO and BOD chairperson, (3) the percentage of independent directors in the BOD equal to and over $1 / 3$ and (4) the percentage of independent directors in the BOD over 1/3. Secondly, professionals to the BOD are characterized by including (1) BOD members with financial expertise and (2) the existence of the Technical Committee. Thirdly, behaviors of the BOD are characterized by including (1) BOD meeting frequency, (2) ownership proportion of the BOD, (3) the percentage of directors concurrent holding the position of BOD chairperson. Further, the study also analyzes the impact of other factors (control variables) on FRQ such as company size, financial leverage, etc. A study conducted in Portugal (by Alves, 2014) regarding the impact of BOD independence on FRQ. In addition, the author also further analyzed the relationship of other factors, i.e. financial leverage, net cash flows, investment opportunities, type of audit company and company size. Consistent results show that only the type of audit company does not have an impact on FRQ while the rest do. A number of studies about the impact of the BOD on FRQ through EM such as those by Abed, Al-Attar, \& Suwaidan, 2012 in Arab countries; Waweru \& Riro, 2013 in Kenyan in Africa; Ahmed, 2014 in Bursa Malaysia stock market; Aygun, Ic, \& Sayim, 2014 in Turkey.

In studies about the impact of the BOD on FRQ, the research findings in the world are inconsistent. For example, regarding BOD factors, size, in a positive direction, a large-sized BOD can ensure a higher FRQ as the larger number of BOD members experienced in financial management can supervise and control better management activities (Marrakchi Chtourou et al., 2001; Xie et al., 2003). In a negative direction, a large-sized BOD can make it more difficult to control accounting-financial information due to the cost and time required to timely convey information between the director and the board of directors. Furthermore, the different and sometimes conflicting opinions of a large-sized BOD can put pressure on the BOD, forcing them to conduct EM or commit financial statement fraud (Abdul Rahman \& Haneem Mohamed Ali, 2006). Or the factor, the independent member percentage, independent members of BOD can better supervise and control management activities and make important decisions such as on corporate restructure or dismissal of directorate members, thereby indirectly serving to maximize shareholder benefits (Xie et al., 2003; Peasnell et al., 2005). Inversely, independent BOD members may find it difficult to manage FRQ as they have less information about the company's specific activities, the independence of independent BOD members is unclear, and their role of supervision in the BOD has not been brought into the fullest play (Park \& Shin, 2004). Also, such as the duality of the BOD chairperson, when too much power falls into the hands of a person, the manipulation of financial information will easily occur (Saleh, Iskandar, \& Rahmat, 2005). Quantitative research, nevertheless, shows that this duality does not always have a negative impact on FRQ. Finkelstein \& D'aveni, 1994 have tested and concluded that a few companies tend to let the BOD chairperson hold concurrently the position of chief executive officer as they can avoid the problem of conflict in managing, controlling and supervising business activities.

Some studies measure FRQ under the model of Patricia M Dechow \& Dichev, 2002. For example, in a study by S. U. Hassan \& Bello, 2013 about the monitoring and FRQ characteristics of manufacturing companies listed in Nigeria. The findings show that the factors of Financial leverage, directorate independence, ownership proportion by the organization, size, independence, number of meetings have a positive impact, only ownership proportion by managers has a negative impact on FRQ. Alzoubi, 2012 used EM to evaluate FRQ and provided a research framework on the relationship of the directorate characteristics with EM. The researcher summarized previous studies and presented the research framework with factors influencing EM including directorate independence, CEO duality, BOD financial expertise, BOD size, BOD meetings. Houqe, van Zijl, Dunstan, \& Karim, 2012 studied the impact of corporate governance practices on FRQ in Bangladesh. The research findings show that corporate governance mechanism has a positive impact on the company's FRQ. Klai \& Omri, 2011 studied the impact of governance mechanism on FRQ with a research sample of 22 companies listed on the Tunis Stock Exchange from 1997-2007. The researchers focused on studying factors related to the directorate characteristics and the capital ownership structure, as well as the reputation of independent auditors. The research findings show that the factors of ownership by the state, ownership by the organization, the directorate size, the percentage of independent directorate members, CEO duality have a positive 
impact and the factors of ownership by foreigners, concentration of ownership, ownership by family members, corporate size, development prospect (market price to book ratio) have a negative impact on FRQ.

So, there have been many research works on BOD factors influencing FRQ in the world, in which FRQ can be measured in different ways, each research usually focuses on one or several groups of BOD factors, company characteristics and the findings are inconsistent. The overview research also shows that in a developing economy, there exist legal regulations, business environment and stock market development which are still incomplete. Therefore, researching the impact of the BOD on FRQ will be of great significance. Furthermore, this research will continue to expand and examine the impact of the BOD on FRQ.

\section{Research Methodology}

\subsection{Research Model}

This research uses the proposed regression models to classify the impact of the BOD on FRQ of companies as discussed in the literature review, specifically as follows:

$$
\begin{aligned}
\text { FRQ }_{\mathrm{i}, \mathrm{t}} & =\beta_{0}+\beta_{1} \text { BSIZE }_{\mathrm{i}, \mathrm{t}}+\beta_{2} \text { BDIND }_{\mathrm{i}, \mathrm{t}}+\beta_{3} \text { BMEET }_{\mathrm{i}, \mathrm{t}}+\beta_{4} \text { BDUAL }_{\mathrm{i}, \mathrm{t}}+\beta_{5} \text { BGENR }_{\mathrm{i}, \mathrm{t}}+\beta_{6} \mathrm{BIG}_{\mathrm{i}, \mathrm{t}} \\
& +\beta_{7} \text { SIZE }_{\mathrm{i}, \mathrm{t}}+\beta_{8} \mathrm{LEV}_{\mathrm{i}, \mathrm{t}}++\varepsilon_{\mathrm{i}, \mathrm{t}}
\end{aligned}
$$

To measure FRQ, we base ourselves on the quality of accruals (Patricia M Dechow \& Dichev, 2002) to use working capital accruals regressed with operating cash flow of the previous year, the current year and the following year, all divided by the beginning total assets.

$$
\frac{W C A_{i t}}{A_{i t-1}}=\alpha_{1} \frac{C F O_{i t-1}}{A_{i t-1}}+\alpha_{2} \frac{C F O_{i t}}{A_{i t-1}}+\alpha_{3} \frac{C F O_{i t+1}}{A_{i t-1}}
$$

Where: $W C A_{i t}$ is working capital accruals of enterprise $\mathrm{i}$ in year $\mathrm{t}$, calculated by the change in short-term assets $(\triangle \mathrm{CA})$ minus the change of cash and cash equivalents ( $\triangle \mathrm{Cash}$ ), minus the change in $(\triangle \mathrm{CL})$ and plus the change in short-term bank debt $(\Delta \mathrm{Debt})$.

$C F O_{i t-1} C F O_{i t}, C F O_{i t+1}$ are respectively operating cash flows in year $\mathrm{t}-1$, year $\mathrm{t}$ and year $\mathrm{t}+1$. All variables are divided by the beginning total assets ( $A_{i t-1}$-Total assets).

To measure FRQ, a representative variable created from the residual of equation (2) after performing regression. The absolute residual value of each observation is inversely related to the quality of residual accruals. So, higher residual value represents a lower quality of residual accruals. To make the interpretation of this variable easy, the quality of residual accruals is determined to be a negative value of the absolute residual value. The variables in model (1) are presented in Table 1.

Table 1. Variable measurement

\begin{tabular}{lllll}
\hline Abbreviation & Variable & Measurement & $\begin{array}{l}\text { Impact } \\
\text { expected }\end{array}$ \\
\hline FRQ & $\begin{array}{l}\text { Financial } \\
\text { Quality }\end{array}$ & Reporting & $\begin{array}{l}\text { The absolute value of the model residual estimates the } \\
\text { quality residual accruals is multiplied by }(-1) . \\
\mathrm{CACC}_{\mathrm{it}}=\alpha+\beta_{1} \mathrm{CFO}_{\mathrm{it}-1}+\beta_{2} \mathrm{CFO}_{\mathrm{it}}+\beta_{3} \mathrm{CFO}_{\mathrm{it}+1}+\varepsilon_{\mathrm{it}}\end{array}$ \\
\hline BSIZE & Size of Board of Directors & $\begin{array}{l}\text { Number of BOD members } \\
\text { BDIND }\end{array}$ & $\begin{array}{l}\text { Board of Directors } \\
\text { independence }\end{array}$ & $\begin{array}{l}\text { Number of independent BOD members/Total number } \\
\text { of BOD members }\end{array}$ \\
\hline BMEET & $\begin{array}{l}\text { Board of Directors } \\
\text { meeting frequency }\end{array}$ & Number of BOD meetings & + \\
\hline BDUAL & $\begin{array}{l}\text { Board of Directors } \\
\text { chairperson duality }\end{array}$ & $\begin{array}{l}\text { Is equal to 1 when CEO holds concurrently the position } \\
\text { of BOD chairperson and equal to 0 in the opposite case }\end{array}$ \\
\hline BGENR & $\begin{array}{l}\text { Percentage of female } \\
\text { BOD members }\end{array}$ & $\begin{array}{l}\text { Number of female BOD members/Total BOD } \\
\text { members }\end{array}$ & + \\
\hline
\end{tabular}




\begin{tabular}{lllc}
\hline BIG4 & Size of audit company & $\begin{array}{l}\text { The binary variable takes a value of 1 if audited by } \\
\text { Big4 audit company }\end{array}$ & + \\
\hline SIZE & Size of the company & Log base 10 of total assets & + \\
\hline LEV & Debt ratio & Total liabilities / Total assets & + \\
\hline
\end{tabular}

Source: Authors

\subsection{Data}

The research examines the impact of the BOD on FRQ of enterprises listed on the stock market in Vietnam from 2010-2018 with 2162 observations. The data is collected from financial statements of these companies and the dataset of Vietstock, as well as aggregated from the data published on several reputable securities websites such as cafef.vn or cophieu68.com. The initial data will be synthesized and calculated again in the same way of determining variables, where some variables are regressed to get the residual and initialize the corresponding new variable through Stata 14.0 software.

\subsection{Research Method}

The research uses the Fixed Effect and Random Effect regression methods to estimate the impact of the BOD on FRQ of companies listed in Vietnam. The research paper will use F-Test and Hausman Test to determine between Fixed Effect and Random Effect which method produces better results, so as to check for the defects of the model selected and find way to remedy the model by applying GLS method.

\section{Research Findings and Dicussions}

According to the results in Table 2, the FRQ variable has a mean value of -0.087 , with a standard deviation of 0.100 ; the average number of BOD members is 5.56 members, the highest is 12 and the lowest 3 members. The percentage of independent non-executive BOD members is $68.2 \%$; the lowest is $20 \%$ and the highest $100 \%$. The average number of BOD meetings is 10.14, of which the lowest is 1 and the highest 78 . On average, 24.3\% of enterprises have a BOD chairperson cum CEO. The average percentage of female BOD members is $15.8 \%$. There are $25.3 \%$ of enterprises audited by a Big4 audit company; the corporate size by assets after Logarithm is 11.749 on average; the average liabilities to total assets ratio is $50.5 \%$.

Table 2. Descriptive analysis

\begin{tabular}{llllll}
\hline Variable & Obs & Mean & Std.Dev & Min & Max \\
\hline FRQ & 2162 & -0.087 & 0.100 & -0.9136 & -0.0000837 \\
\hline BSIZE & 2162 & 5.558 & 1.330 & 3 & 12 \\
\hline BIND & 2162 & 0.682 & 0.171 & 0.2 & 1 \\
\hline BMEET & 2162 & 10.142 & 9.816 & 1 & 78 \\
\hline BDUAL & 2162 & 0.243 & 0.429 & 0 & 1 \\
\hline BGENR & 2162 & 0.158 & 0.179 & 0 & 1 \\
\hline BIG4 & 2162 & 0.253 & 0.435 & 0 & 1 \\
\hline LEV & 2162 & 0.505 & 0.212 & 0.012 & 0.993 \\
\hline SIZE & 2162 & 11.749 & 0.694 & 10.132 & 14.459 \\
\hline
\end{tabular}

Source: Calculated by Stata 14.0

In the Table 3, we can see the impact direction between the research variables. The purpose of checking the close correlation between independent and dependent variables is to eliminate factors that may lead to multicollinearity before running regression models. The correlation coefficient between the independent variables in the model does not have any pair greater than 0.8 , therefore multi-collinearity is less likely to occur, when using regression model of VIF authors group to check. 
Table 3. Correlation matrix

\begin{tabular}{|c|c|c|c|c|c|c|c|c|c|}
\hline & FRQ & BSIZE & BIND & BMEET & BDUAL & BGENR & BIG4 & LEV & SIZE \\
\hline FRQ & 1 & & & & & & & & \\
\hline BSIZE & 0.0302 & 1 & & & & & & & \\
\hline BIND & 0.0343 & 0.1646 & 1 & & & & & & \\
\hline BMEET & -0.128 & 0.0031 & 0.0373 & 1 & & & & & \\
\hline BDUAL & 0.0316 & -0.076 & -0.251 & -0.091 & 1 & & & & \\
\hline BGENR & 0.0286 & 0.0042 & 0.039 & 0.0829 & 0.029 & 1 & & & \\
\hline BIG4 & 0.0017 & 0.1992 & 0.0131 & 0.1846 & -0.06 & -0.046 & 1 & & \\
\hline LEV & 0.0242 & -0.022 & -0.119 & 0.208 & 0 & -0.083 & 0.023 & 1 & \\
\hline SIZE & -0.098 & 0.3659 & 0.0354 & 0.3232 & 0.0017 & -0.07 & 0.5208 & 0.3233 & 1 \\
\hline
\end{tabular}

Source: Calculated by Stata 14.0

On the basis of results in Table 4, with the regression results by the GLS method, we come up with some discussions as follows:

- Regarding BOD size, the research findings show that BOD size is positively associated with FRQ, consistent with the initial expectations, this research result is consistent with previous research on the impact of BOD size on FRQ by Abed et al. (2012), Aygun et al. (2014), Xie et al. (2003), inconsistent with the study by Qinghua et al. (2007). Thus, this test result points out that the larger the BOD size, the more positive the impact on FRQ. This research finding is consistent with the author's expectations based on the explanation of the resource dependency theory

- Regarding BOD independence, the test results show that BOD independece has a positive impact on FRQ, i.e. the higher the BOD independence, the higher FRQ, consistent with the expectations established. This finding is consistent with the previous studies by Xie et al. (2003), Qinghua et al. (2007), S. U. Hassan \& Bello (2013), Waweru \& Riro (2013); but inconsistent with the study by Liu (2012) purporting that the BOD independence has a negative impact on FRQ; and also our findings are inconsistent with the studies by Chalaki et al. (2012), Abed et al. (2012), which found no impact.

- Regarding BOD meeting frequency, the research findings show that BOD meeting frequency is negatively related to FRQ, contrary to the initial expectations, the result points out that BOD meeting frequency in enterprises reduces FRQ, thus inconsistent with the finding by S. U. Hassan \& Bello (2013).

- Regarding the concrete holding the position of CEO and BOD chairperson, the regression results do not support and have a positive impact. This finding is consistent with the research finding by Finkelstein \& D'aveni (1994). This indicates that a company with the CEO cum BOD chairperson has a higher FRQ higher than a company where such duality does not exist. This can be explained that companies tend to let the BOD chairperson concurrently hold the position of CEO to avoid the problem of conflict in administering, managing and monitoring business activities. This finding is inconsistent with the research findings by Soliman \& Ragab (2014), Ragab (2013), Liu (2012); and different from that of Abed et al. (2012), Xie et al. (2003) purporting that a company with the CEO not holding concurrently the position of BOD chairperson has no impact on FRQ.

- Female BOD members are positively related to FRQ, but only statistically significant at $10 \%$, thus BOD gender diversity does not impact on FRQ. This finding is different from that of the research by Arun, Almahrog, \& Aribi (2015).

Table 4. Regression results

\begin{tabular}{lllll}
\hline & VIF & Mô hình FEM & Mô hình REM & Mô hình GLS \\
\hline BSIZE & 1.24 & 0.00202 & $0.00556^{* *}$ & $0.00535^{* * *}$ \\
\hline BIND & 1.12 & -0.0192 & -0.00858 & $0.0321^{* *}$ \\
\hline
\end{tabular}




\begin{tabular}{|c|c|c|c|c|}
\hline BMEET & 1.2 & 0.000557 & -0.0000661 & $-0.00117 * * *$ \\
\hline BDUAL & 1.09 & $-0.0245 * * *$ & -0.0117 & $0.0106 * *$ \\
\hline BGENR & 1.03 & $0.0461 *$ & 0.0314 & $0.0201 *$ \\
\hline BIG4 & 1.44 & -0.00659 & $0.0300 * * *$ & $0.0232 * * *$ \\
\hline LEV & 1.24 & $0.141 * * *$ & $0.102 * * *$ & $0.0536 * * *$ \\
\hline SIZE & 1.97 & $-0.171 * * *$ & $-0.0903 * * *$ & $-0.0252 * * *$ \\
\hline _cons & & $1.850 * * *$ & $0.889 * * *$ & $0.131 * * *$ \\
\hline $\mathrm{N}$ & & 2162 & 2162 & 2162 \\
\hline R-sq & & 0.178 & & \\
\hline \multirow{2}{*}{ Kiểm định $\mathrm{F}$} & & \multicolumn{2}{|c|}{$\mathrm{F}(8,1901)=51.58$} & \\
\hline & & Prob $>F=$ & & \\
\hline \multirow{2}{*}{ Kiểm định LM } & & & Wald chi2 $(8)=222.25$ & Wald chi2 $(8)=93.39$ \\
\hline & & & Prob $>$ chi $2=0.0000$ & Prob $>$ chi $2=0.0000$ \\
\hline \multirow{2}{*}{$\begin{array}{l}\text { Kiểm định } \\
\text { Hausman }\end{array}$} & \multicolumn{3}{|c|}{$\operatorname{chi} 2(8)=198.00$} & \\
\hline & \multicolumn{3}{|c|}{ Prob $>$ chi $2=0.0000$} & \\
\hline \multirow{2}{*}{$\begin{array}{l}\text { Modified Wald } \\
\text { test }\end{array}$} & \multicolumn{3}{|c|}{$\operatorname{chi} 2(253)=6.3 e+07$} & \\
\hline & \multicolumn{3}{|c|}{ Prob>chi $2=0.0000$} & \\
\hline \multirow{2}{*}{ Wooldridge test } & \multicolumn{3}{|c|}{$\mathrm{F}(1,248)=969.229$} & \\
\hline & \multicolumn{3}{|c|}{ Prob $>F=0.0000$} & \\
\hline \multicolumn{5}{|c|}{$\mathrm{t}$ statistics in brackets $* \mathrm{p}<0.1, * * \mathrm{p}<0.05, * * * \mathrm{p}<0.01$} \\
\hline
\end{tabular}

Source: Calculated by Stata 14.0

- Regarding audit company, the research finding with coef. $=0.0213$, significance level of $1 \%$ shows that enterprises audited Big4 audit companies will increase FRQ, i.e. when the companies are audited by reputable, large-scale companies as represented by Big4 will increase FRQ. This research finding supports the author's expectations as well as the signaling theory, agency theory, with the explanation that Big4 companies have good professional team, experience and strict audit process thus causing Big4-audited companies to become more reluctant when conducting EM behavior leading to increased FRQ. This finding is consistent with that of the research by Xie et al. (2003.)

- Regarding corporate size variable, with coef. $=-0.0258$ and significance level of $1 \%$, this research finding shows corporate size (SIZE) has a negative impact on FRQ. This means that as the corporate size grows, enterprises tend to reduce FRQ through the increased flexible use of prescribed accounting policies to perform EM behaviors. This finding is inconsistent with that of the studies by Soliman \& Ragab (2014); Dang, Vu, Ngo, \& Hoang (2019); T. V. Ha, Dang, Tran, Van Vu, \& Trung (2019); Van, Hung, Van, \& Xuan (2019); Hung, Do Hoai Linh, Hoa, \& Ha (2018); Van Khanh \& Hung (2020). This research finding also acknowledges that the larger the corporate size, the more likely the manager tends to use sales policies, discount operations to increase EM behaviours, thereby resulting in reduced FRQ.

- Regarding debt ratio, regression result with coef. $=0.0387$ and significance level of $1 \%$, this means that the higher the ratio of liabilities the company has, the higher FRQ will be. Thus, this research finding is inconsistent with the view of Waweru \& Riro (2013); Rahmani \& Akbari (2013); Van Linh, Hung, Dang, Van, \& Anh (2019); H. T. V. Ha, Van, \& Hung (2019).

\section{Conclusion and Recommendations}

By using a sample including 2162 observations at enterprise listed on Vietnam's stock market from 2010 -2018 to test the impact of the BOD on FRQ, the research shows that BOD size, independence and chairperson duality have a positive impact on the enterprise's FRQ. Meanwhile BOD meeting frequency is negatively related to and the percentage of female BOD members has no impact on FRQ. At the same time the research also examines a number of 
control variables such as audit quality (Big4), corporate size and financial leverage that affect FRQ. Proceeding from the research findings, the authors propose some policy implications as follows:

- The empirical research findings have provided reliable proofs for enterprise to propose useful solutions for themselves. Specifically: (1) The research findings have acknowledged that effective BOD increases FRQ of the enterprise. The enterprise, therefore, needs to have a deep understanding the role played by the BOD in FRQ. Specifically, the enterprise must complete the BOD model according to OECD (Organization for Economic Co-operation and Development), BOD regulations; especially build a BOD structure that meets the composition requirements for the number of members; the percentage of independent members must account for at least one third of the total number; the female BOD member percentage; the existence of concurrent holding the position of BOD chairperson and CEO; holding more effective and dynamic BOD meetings.

- In order to attract investors' attention, enterprises should provide further information related to FRQ measurement models, support investors, analytics experts with more adequate information in making decisions. Although the information necessary for the measurement models has been provided through the financial statements, investors who wish to have such information have to take a lot of time to sum up and process; therefore, in the process of providing information on the annual report, enterprises should add more information about FRQ that the measurement models require, through which investors feel they are more cared for and trusted when making their investment decisions.

- The finding of the research on the factor affecting FRQ shows that Big4-audited companies achieve an increase in their FRQ. Accordingly, enterprises should consider choosing large and reputable auditing units to ensure the provided information is of the best quality, thereby increasing the interest of investors. Investors can also review net cash flow from operating activities and debt ratio; because according to corporate size research, the FRQ is increasing, thus this proof provides useful information for investors to make the right decisions, protect and use their capital effectively. At the same time, there is a very important factor, i.e. the quality from the independent audit service. The research findings also acknowledge that enterprise audited by such leading audit companies as Big4 will have the foundation for considering FRQ. Investors, therefore, can rely on information about the audit company on the audited financial statements to consider FRQ, so as to make appropriate investment decisions.

\section{References}

Abdul Rahman, R., \& Haneem Mohamed Ali, F. (2006). Board, audit committee, culture and earnings management: Malaysian evidence. Managerial Auditing Journal, 21(7), 783-804. https://doi.org/10.1108/02686900610680549

Abed, S., Al-Attar, A., \& Suwaidan, M. (2012). Corporate governance and earnings management: Jordanian evidence. International business Research, 5(1), 216-225. http://doi.org/10.5539/ibr.v5n1p216

Ahmed, S. (2014). Board of director characteristics and earnings management in Malaysia. GSTF Journal on Business Review (GBR), 2(4), 94-99. http://doi.org/10.5176/2010-4804_2.4.255

Al-Othman, L. N., \& Al-Zoubi, M. N. (2019). The Impact of the Board of Directors Characteristics on Earnings Quality of Listed Industrial Companies on the Amman Stock Exchange. Academy of Accounting and Financial Studies Journal, 23(1), 1-16.

Alves, S. (2014). The effect of board independence on the earnings quality: evidence from portuguese listed companies. Australasian Accounting, Business and Finance Journal, 8(3), 23-44. http://doi.org/10.14453/aabfj.v8i3.3

Alzoubi, E. S. (2012). Board characteristics and financial reporting quality among Jordanian listed companies: Proposing conceptual framework. Asian Journal of Finance and Accounting, 4(1), 245-258.

Arun, T. G., Almahrog, Y. E., \& Aribi, Z. A. (2015). Female directors and earnings management: Evidence from UK companies. International Review of Financial Analysis, 39, 137-146.

Aygun, M., Ic, S., \& Sayim, M. (2014). The Effects of corporate ownership structure and board size on earnings management: Evidence from Turkey. International Journal of Business and Management, 9(12), 123-132. http://doi.org/10.5539/ijbm.v9n12p123

Ball, R., \& Shivakumar, L. (2005). Earnings quality in UK private firms: comparative loss recognition timeliness. Journal of Accounting and Economics, 39(1), 83-128. https://doi.org/10.1016/j.jacceco.2004.04.001

Cohen, J. R., Krishnamoorthy, G., \& Wright, A. (2004). The corporate governance mosaic and financial reporting quality. Journal of Accounting Literature, 87-152.

Chaharsoughi, M. T., \& Rahman, R. A. (2013). Corporate governance and earnings quality: the experience of listed companies in Iran. Journal of Modern Accounting and Auditing, 9(6), 790-797. 
Chalaki, P., Didar, H., \& Riahinezhad, M. (2012). Corporate governance attributes and financial reporting quality: Empirical evidence from Iran. International Journal of Business and Social Science, 3(15), 223-229.

Dang, H. N., Vu, V. T. T., Ngo, X. T., \& Hoang, H. T. V. (2019). Study the Impact of Growth, Firm Size, Capital Structure, and Profitability on Enterprise Value: Evidence of Enterprises in Vietnam. Journal of Corporate Accounting \& Finance, 30(1), 144-160. https://doi.org/10.1002/jcaf.22371

Dechow, P. M., \& Dichev, I. D. (2002). The quality of accruals and earnings: The role of accrual estimation errors. The Accounting Review, 77(s-1), 35-59. https://doi.org/10.2308/accr.2002.77.s-1.35

Dechow, P. M., Kothari, S. P., \& Watts, R. L. (1998). The relation between earnings and cash flows. Journal of Accounting and Economics, 25(2), 133-168. https://doi.org/10.1016/S0165-4101(98)00020-2

Dechow, P., Ge, W., \& Schrand, C. (2010). Understanding earnings quality: A review of the proxies, their determinants and their consequences. Journal of Accounting and Economics, 50(2-3), 344-401. https://doi.org/10.1016/j.jacceco.2010.09.001

Ebrahim, A. (2007). Earnings management and board activity: an additional evidence. Review of Accounting and Finance, 6(1), 42-58. https://doi.org/10.1108/14757700710725458

Epstein, B. J., \& Jermakowicz, E. K. (2008). IFRS Policies and Procedures. John Wiley \& Sons.

Finkelstein, S., \& D'aveni, R. A. (1994). CEO duality as a double-edged sword: How boards of directors balance entrenchment avoidance and unity of command. Academy of Management Journal, 37(5), 1079-1108. https://doi.org/10.5465/256667

Freeman, R. E. (1984). Strategic Management: A Stakeholder Approach. Pitman, Boston, MA.

Gulzar, M. A. (2011). Corporate governance characteristics and earnings management: Empirical evidence from Chinese listed firms. International Journal of Accounting and Financial Reporting, 1(1), 133-151. http://doi.org/10.5296/ijafr.v1i1.854

Ha, H. T. V., Van, V. T. T., \& Hung, D. N. (2019). Impact of Social Reponsibility Information Disclosure on the Financial Performance of Enterprises in Vietnam. Indian Journal of Finance, 13(1), 20-36. http://doi.org/10.17010/ijf/2019/v13i1/141017

Ha, T. V., Dang, N. H., Tran, M. D., Van Vu, T. T., \& Trung, Q. (2019). Determinants Influencing Financial Performance of Listed Firms: Quantile Regression Approach. Asian Economic and Financial Review, 9(1), 78-90. http://doi.org/10.18488/journal.aefr.2019.91.78.90

Hashim, H. A., \& Devi, S. (2008). Board characteristics, ownership structure and earnings quality: Malaysian evidence. Research in Accounting in Emerging Economies, 8(97), 97-123. https://doi.org/10.1016/S1479-3563(08)08004-3

Hassan, S. U., \& Ahmed, A. (2012). Corporate governance, earnings management and financial performance: A case of Nigerian manufacturing firms. American International Journal of Contemporary Research, 2(7), 214-226.

Hassan, S. U., \& Bello, A. (2013). Firm characteristics and financial reporting quality of listed manufacturing firms in Nigeria. International Journal of Accounting, Banking and Management, 1(6), 47-63.

Hillman, A. J., \& Dalziel, T. (2003). Boards of directors and firm performance: Integrating agency and resource dependence perspectives. Academy of Management Review, 28(3), 383-396. https://doi.org/10.5465/amr.2003.10196729

Houqe, M. N., van Zijl, T., Dunstan, K., \& Karim, A. W. (2012). The effect of IFRS adoption and investor protection on earnings quality around the world. The International Journal of Accounting, 47(3), 333-355.

Hung, D. N., Do Hoai Linh, T. T. V., Hoa, T. M. D., \& Ha, H. T. V. (2018). Factors Influencing Accrual Earnings Management and Real Earnings Management: The Case of Vietnam. Paper presented at the Proceedings of 14 th International Conference on Humanities and Social Sciences 2018 ThaiLan.

Jensen, M. C., \& Meckling, W. H. (1976). Theory of the firm: Managerial behavior, agency costs and ownership structure. Journal of Financial Economics, 3(4), 305-360.

Klai, N., \& Omri, A. (2011). Corporate governance and financial reporting quality: The case of Tunisian firms. International Business Research, 4(1), 158-166.

Klein, A. (2002). Audit committee, board of director characteristics, and earnings management. Journal of Accounting and Economics, 33(3), 375-400. 
Liu, J. (2012). Board monitoring, management contracting and earnings management: an evidence from ASX listed companies. International Journal of Economics and Finance, 4(12), 121-136.

Mackenzie, B., Coetsee, D., Njikizana, T., Chamboko, R., Colyvas, B., \& Hanekom, B. (2012). Wiley IFRS 2013: Interpretation and Application of International Financial Reporting Standards. John Wiley \& Sons.

Marrakchi Chtourou, S., Bedard, J., \& Courteau, L. (2001). Corporate governance and earnings management (pp. 1-35).

Murhadi, W. R. (2011). Good corporate governance and earning management practices: An Indonesian cases. Jurnal Manajemen, 10(2), 143-155.

Nicholson, G. J., \& Kiel, G. C. (2007). Can directors impact performance? A case-based test of three theories of corporate governance. Corporate Governance: An International Review, 15(4), 585-608. https://doi.org/10.1111/j.1467-8683.2007.00590.x

Park, Y. W., \& Shin, H.-H. (2004). Board composition and earnings management in Canada. Journal of Corporate Finance, 10(3), 431-457.

Peasnell, K. V., Pope, P. F., \& Young, S. (2005). Board monitoring and earnings management: Do outside directors influence abnormal accruals?. Journal of Business Finance \& Accounting, 32(7-8), 1311-1346.

Pfeffer, J., \& Salancik, G. R. (1978). Social control of organizations. The external control of organizations: A resource dependence perspective.

Qinghua, W., Pingxin, W., \& Junming, Y. (2007). Audit committee, board characteristics and quality of fi nancial reporting: An empirical research on Chinese securities market. Frontiers of Business Research in China, 1(3), 385-400.

Rahmani, S., \& Akbari, M. A. (2013). Impact of firm size and capital structure on earnings management: evidence from Iran. World of Sciences Journal, 1(17), 59-71.

Ross, S. A. (1977). The determination of financial structure: the incentive-signalling approach. The Bell Journal of Economics, 8(1), 23-40.

Saleh, N. M., Iskandar, T. M., \& Rahmat, M. M. (2005). Earnings management and board characteristics: Evidence from Malaysia. Jurnal Pengurusan (UKM Journal of Management), 24.

Schipper, K., \& Vincent, L. (2003). Earnings quality. Accounting Horizons, 17, 97-110.

Soliman, M. M., \& Ragab, A. A. (2014). Audit committee effectiveness, audit quality and earnings management: an empirical study of the listed companies in Egypt. Research Journal of Finance and Accounting, 5(2), 155-166.

Spence, M. (1973). Job market signaling. The Quarterly Journal of Economics, 87(3), 355-374.

Van Beest, F., Braam, G., \& Boelens, S. (2009). Quality of Financial Reporting: measuring qualitative characteristics. Nijmegen Center for Economics (NiCE). Working Paper (pp. 09-108).

Van Khanh, V. T., \& Hung, D. N. (2020). Impact of Earnings Quality on the Debt Maturity: The Case of Vietnam. Asian Economic and Financial Review, 10(1), 1-12.

Van Linh, N., Hung, D. N., Dang, T. B., Van, V. T. T., \& Anh, N. T. M. (2019). The Effects of Business Efficiency to Disclose Information of Sustainable Development: The Case of Vietnam. Asian Economic and Financial Review, 9(4), 547-558.

Van, H. T. T., Hung, D. N., Van, V. T. T., \& Xuan, N. T. (2019). Managing Optimal Working Capital and Corporate Performance: Evidence from Vietnam. Asian Economic and Financial Review, 9(9), 977-993.

Watson, A., Shrives, P., \& Marston, C. (2002). Voluntary disclosure of accounting ratios in the UK. The British Accounting Review, 34(4), 289-313. https://doi.org/10.1006/bare.2002.0213

Waweru, N. M., \& Riro, G. K. (2013). Corporate governance, firm characteristics and earnings management in an emerging economy. Journal of Applied Management Accounting Research, 11(1), 43-64.

Xie, B., Davidson, W. N., \& DaDalt, P. J. (2003). Earnings management and corporate governance: the role of the board and the audit committee. Journal of Corporate Finance, 9(3), 295-316. 